\title{
THE BLACK CUCKOO-SHRIKE Campephaga flava: A NEW RECORD FOR THE MOUNTAIN ZEBRA NATIONAL PARK AND THE CRADOCK DISTRICT, CAPE PROVINCE
}

\section{I.A.W. MACDONALD}

Percy Fitzpatrick Institute of African Ornithology

University of Cape Town

Rondebosch

7700

The avifauna of the Mountain Zebra National Park (MZNP) has been recorded over a period of some two decades (Skead 1965, Koedoe 8: 1-40; Penzhorn \& Bronkhorst 1976, Koedoe 19: 171-174; Penzhorn 1977, Koedoe 20: 205-207; Grobler \& Bronkhorst 1981, Koedoe 24: 199-203). Collett (1982 Southern Birds 9: 1-65) has summarised all the available information on the avifauna of the Cradock district assembled since the turn of the century. Although 203 species are recorded from the MZNP by these authors (and a further four in the roneoed checklist for the park (Anon, updated, National Parks Board of Trustees, roneod, $15 \mathrm{pp}$ )) no mention is made of the Black Cuckoo-Shrike Campephaga flava. Collett (1982) does not list it for the Cradock district.

During the period 14-18 December 1983 incidental observations were made on the birdlife of the MZNP during a survey of alien biota occurring in the park. In total 75 of the listed avifauna were recorded. In addition the Black Cuckoo-Shrike was recorded on two occasions. On 16 December 1983 the characteristic "trilling" call of this species (Skead 1966, Ostrich 37: 71-75) was heard in dense Acacia karroo riverine woodland below the dam wall in Fonteinkloof $\left(32^{\circ} 16^{\prime} \mathrm{S}, 25^{\circ} 27^{\prime} \mathrm{E}\right)$. The call was followed until an adult

- male of the species, showing the diagnostic red gape flanges, was clearly observed using $8 \times 40$ binoculars at a distance of some $40 \mathrm{~m}$. On 17 December the call was again recorded coming from dense Acacia karroo woodland in Grootkloof but on this occasion the bird was not seen.

The occurrence of this species in the MZNP is not unexpected as Skead (1967, Ostrich Suppl. 7: 1-103) lists it as occurring "in the bushveld of the coastal and sub-coastal districts" of the eastern Cape. In this area he records that "although the Black Cuckoo-Shrike will be at any one locality in any month of the year it is not necessarily a consistent occupant of any one place. It is a wanderer. Once it does appear, it is immediately conspicuous, but such a visit may last only a day or two, or as long as a month followed by an irregular absence" (Skead 1966). On the eastern seaboard of southern Africa the species is now generally known to be subject to movements, the exact nature of which are not yet understood (e.g. Morse Jones 1965, South 
Afr. Avifauna Series 28: 1-34); Niven \& Niven 1966,South Afr. Avifauna Series 34: 1-55; Vernon 1972, South Afr. Avifauna Series 83: 1-51). Further north there are clear indications of a seasonal altitudinal and latitudinal migration (Britton 1973, Bull. Brit. Ornith. Cl. 93: 41-48; Irwin 1981, The Birds of Zimbabwe). It has been suggested that variations in the extent of these movements in the more arid savannas of southern Africa are linked to short-term fluctuations in rainfall (Macdonald 1982, M.Sc. thesis, University of Natal, Durban). Future observers should look out for this species in the MZNP.

The National Parks Board of Trustees are thanked for their permission to the author to work in the MZNP. The author's research is funded by the National Programme for Environmental Sciences of the Council for Scientific and Industrial Research. 